\title{
Factors of variation, maintenance and change in Scandinavian heritage languages
}

\author{
Janne Bondi Johannessen \\ Center for Multilingualism in Society across the Lifespan, University of Oslo, \\ Norway
}

\begin{abstract}
Aims and objectives/purpose/research questions: I investigate variation and change in heritage languages, focusing on descendants of $19^{\text {th }}-/$ early $20^{\text {th }}$-century North Germanic immigrant languages in America. I compare a battery of predictors (e.g. token frequency, language attitude) against a baseline grammar, something often framed in terms of 'transfer', 'incomplete acquisition' and 'attrition'. I examine which particular changes have been attributed to which factors.
\end{abstract}

Design/Methodology/Approach, Data and Analysis: I synthesize and draw new conclusions from previous research on heritage Scandinavian.

Findings/Conclusions: Relevant factors belong to two main categories: those favouring maintenance and those more likely to trigger change. Factors that support maintenance are structural ones (typically syntax, phonology and morphology), frequency of use, and external factors. Factors that contribute to change are articulation, language attitudes, and a series of cognitive aspects: incomplete acquisition and attrition, transfer and convergence, processing, memory, complexity, and overgeneralisation.

Originality: I undertake a comparative synthesis of patterns of change and nonchange from baseline varieties.

Significance and Implications: This opens a door to investigating how factors correlate, what causal connections can be found, and what levels of language are affected by what factors.

\section{Keywords}

Scandinavian, North Germanic, heritage language, variation, change, maintenance, immigrant language

\section{Introduction}

I review key factors contributing to variation and change - or maintenance - in Scandinavian heritage languages in North America. ${ }^{1}$ The focus is on heritage Danish, Norwegian and Swedish, all widely researched as witnessed by collected volumes like Page \& Putnam (2015), Johannessen \& Salmons (2015) and the WILA workshop series. Heritage Icelandic, also widely researched, is included in this study due to its genetic and socio-historical connections. While all these languages are typologically and genetically very similar, we also find interesting historical differences. Focusing on closely related languages may help us tease apart what factors contribute to maintenance and change.

A heritage language is a minority language learned in the family that exists alongside a majority language. It is usually the first language they learn, but it often ends up as their non-dominant language (Rothman, 2009, Benmamoun, Montrul \& Polinsky, 2013a, 2013b). This definition includes heritage languages (traditional and

\footnotetext{
${ }^{1}$ I use 'Scandinavian' and 'North Germanic' interchangeably, referring to Norwegian, Swedish, Danish and Icelandic.
} 
modern) as well as native languages in colonised settings. Traditional heritage immigrant languages include languages brought by European immigrants to America in the 18th and especially from the19th century onwards until World War 1, as well as modern ones where immigration happens today. Both groups have a 'hearth' language elsewhere. Speakers of traditional heritage languages are often not fully literate in them.

It is often observed that heritage languages (traditional and modern) have undergone changes and differ from 'baseline' varieties. The homeland language is generally used as baseline, i.e. the language of monolingual speakers from overseas, sometimes a century or more ago (with traditional heritage speakers). Though the social and linguistic context of homeland languages are very different, a baseline language makes comparison possible: to investigate what has changed and, equally interesting, what has not. It is therefore used by many scholars, including Polinsky (2008, 2011) and Rothman (2007) and here.

Other evidence can be used for comparison, such as that of first or second language learners. This can contribute to understanding whether or to what extent factors influencing heritage language grammars are the same as those involved in other types of language bilingualism or acquisition. Rothman (2007), Montrul (2010, 2013) and Polinsky (2011), among others, employ such comparisons.

We cannot assume that today's heritage speakers have personally developed traits that are different from the baseline. These differences may have developed in earlier generations, which means that the input they have been subjected to may be very different.

Countless studies show that modern heritage languages also change, see Benmamoun, Polinsky \& Montrul (2013a, 2013b), or work by Pieter Muysken, Suzanne Aalberse, Francesca Moro (this volume) and Jason Rothman. It would be interesting to see if the changes in the two types of heritage languages, i.e. older heritage languages as opposed to modern heritage languages, have the same direction and type. Present research on heritage Scandinavian cannot yet answer this question, both because there is still much to do on traditional heritage languages, and because there is little research on modern heritage Scandinavian to date (Håkansson, 1995, is an exception). Comparative studies get us closer to how language operates cognitively in the individual and the society.

The paper is structured according to levels of linguistic structure (lexicon, phonology, morphology, syntax and semantics), and for each, findings from previous studies illustrate factors the authors have given as a likely cause for a described phenomenon. According to the studies under discussion, factors of change are articulation and a series of cognitive aspects: incomplete acquisition and attrition, transfer and convergence, processing, memory, complexity, and overgeneralization. ${ }^{2}$ Linguistic levels that favour maintenance are syntax, morphology and phonology, related to which token frequency plays an important role. Language attitudes (Section 4.2) may play a role for both maintenance and change on individual levels, but they

\footnotetext{
${ }^{2}$ Incomplete acquisition describes a situation where learners have had insufficient input to acquire some pattern or structure. The resulting grammar is not deficient, but simply divergent (in the words of Benmamoun et al. 2013b) or differential (Kupisch \& Rothman, 2016). Putnam \& Sánchez (2013) argue against incomplete acquisition, which they see as too tied to exposure to input and the final state of an incomplete grammar. They instead maintain that emphasis should be on the processing of input.
} 
do not influence language shift, which depends more on other factors such as horizontal and vertical ties (see Section 2.1 for details).

Section 2 gives background information on North Germanic immigration to the US and Canada as well as its heritage speakers. Section 3 reviews variation and change at different linguistic levels based on existing research, while Section 4 discusses factors contributing to variation and change. Concluding remarks are provided in Section 5.

\section{Scandinavian immigration and heritage speakers}

To provide some insight into the situation of today's speakers and of North Germanic heritage languages, this section presents key background information.

\subsection{Immigration and institutions in America}

While it has been argued that Norwegians first immigrated to America in 1825 in search of religious freedom (Østrem, 2015), later waves of migration pursued socioeconomic opportunity (Thorsnæs, 2014). By 1920, more than 800,000 people had emigrated to North America from Norway (Myhre, 2015), often through chain migration (Østrem, 2015). Only Ireland had a higher rate of emigration. Norwegian immigrants preferred the rural prairie. According to the 1940 census, for instance, seven out of eight early immigrants were from the countryside, and half of the Norwegians at the time still inhabited towns of fewer than 2,500 (Haugen, 1953, pp. 30-31). Such community structures would likely support language maintenance.

Norwegians built key institutions that promoted "horizontal ties" (Salmons, 2005a, 2005b, Lucht, Frey \& Salmons, 2011): churches, hospitals, old people's homes, Norwegian-language schools and newspapers, and colleges like Luther College (Decorah, Iowa) and St. Olaf College (Northfield, Minnesota), as against "vertical ties", i.e., those between local and central authorities.

Even today, in these towns, the main church is still typically of Norwegian design, with Norwegian names on most graves. In retirement homes, names of inhabitants reveal their Norwegian background, as do decorative elements inside private homes and institutions. The last generation of heritage Norwegian speakers is now old, as are heritage Swedish and heritage Icelandic speakers.

Swedish migrants in North America number more than a million, and they too tend to be predominantly rural (Johannessen \& Salmons, 2015a, p. 12). Hasselmo (1974, p. 14) reports that most Swedish immigrants before 1890 had an agricultural background and were looking for land, mainly in the Upper Midwest. Swedish immigrants also built institutions; new congregations were founded, along with countless Swedish associations, choirs, and newspapers (Hasselmo, 1974, pp. 23-29, Larsson, Tingsell \& Andréasson, 2015, pp. 359-360).

Conversely, Icelandic immigrants were fewer in number, totaling no more than 14,000 in Canada, and immigration generally began later, notably in 1875 . They were clustered on land near Lake Winnipeg, which was reserved for Icelanders alone. They set up their own government in the colony, with a constitution and elections, and had their own schools and newspapers. The early colony was mostly rural. As they were amongst the first immigrants to inhabit the area, incoming foreign farm workers often had to learn Icelandic to get by (Arnbjörnsdóttir, 2006, pp. 26-34, 2015, pp. 74-77, Johannessen \& Salmons, 2015, pp. 9-10). 
Danish immigration differed from these other patterns. Kjær \& Baumann Larsen (1972) describe it as much smaller than the Norwegian and Swedish contexts, with no more than 275,000 for the period 1840-1914. Migrating Danes were typically urbanites, and immigrants from cities preferred New York and other connurbations. Very few settled in groups or formed communities. Furthermore, a substantial proportion were mobile, unmarried men, who later married non-Danish women (Kjær \& Baumann Larsen, 1972, p. 47, Kühl, 2015). Today, very few Danish heritage speakers remain in North America. While the church had a unifying effect in Norwegian and Swedish settlements, the Danish church split, one (Grundtvigian) valuing keeping Danish culture and language, the other (Inner Mission) finding it important to assimilate. The 17,000 Mormons who immigrated from Denmark were not interested in language maintenance as English was their religious language.

\subsection{Current Scandinavian heritage speakers - facts and attitudes}

Present heritage speakers of Norwegian, who will receive the main focus here, are typically between second- and fifth-generation immigrants living in rural areas in small, stable communities. Many have little education and are (retired) farmers. They typically knew no English until they started school, which was a traumatic experience for some. However, younger children were often exposed to English through their older siblings (Rødvand 2017, p. 111). The majority cannot read or write Norwegian, and English is dominant in that it is the language they speak and read daily. Most of these heritage speakers are typically around 80 years old. ${ }^{3}$

Heritage Norwegian is easy to understand for Norwegians from Norway. It has undergone some koinéisation (Hjelde, 2015, Johannessen \& Laake, 2012, 2017), often reflecting input from those dialects spoken in rural Eastern Norway (Johannessen \& Laake, 2012, 2015). However, lack of exposure to modern Norwegian can make it difficult for them to understand researchers with an urban dialect, forcing researchers to accommodate to the heritage language (Johannessen \& Salmons, 2012).

Speakers are generally proud of their Norwegian ancestry, often declaring themselves ' $100 \%$ Norwegian' (meaning that both parents have Norwegian heritage). One question in our interviews is whether they are Norwegian or American. Many look puzzled by the question and answer, "Norwegian, of course!" The role of attitudes is discussed in Section 4.2, where it is concluded that attitudes are not relevant for language shift (contra some of the classic literature on language attitudes, such as Fishman 1991, and with some of the other, e.g. Trudgill \& Tzavaras 1983), but attitudes can influence some levels of language, like lexicon and phonetics.

Even though these heritage speakers label themselves Norwegian, they did not pass on the language to their children. This cannot be due to negative personal attitudes towards the language, but due to Americanisation efforts, and the fact that children were sent to English-speaking schools. It could also be a result of their own negative experiences starting school without knowing English; or they might have wanted a better future for their children. I have asked speakers about this, but they do not know why their children do not speak Norwegian. The answer is the same for whether their spouses are Norwegian speakers or not. It seems that they did not give language much thought. As one speaker wrote to me recently: "Little did we know

\footnotetext{
${ }^{3}$ Some speakers have been to Norway several times and others read and even write Norwegian. This is not to say that such speakers are more "fluent" or "target-like" with respect to the baseline. On the contrary, my impression is that their language varies more, that it has features both from modern and written Norwegian. Some are also relatively young, i.e. in their fifties.
} 
that what we considered insignificant would someday be part of a wide-ranging study of the Norwegian language."

\section{Language variation and change}

Having introduced the heritage speakers and their present and past history in Section 2 , let us turn to examples from recent research on their linguistic production. They illustrate variation and change at different linguistic levels, and form the basis for hypotheses of causal factors discussed in the literature and reviewed here.

\subsection{Changes in Syntax}

Until recently, little attention has been paid to syntactic variation and change in heritage Norwegian in the literature, which might reflect its stability. For instance, Johannessen \& Laake (2015) studied a series of different constructions amongst Norwegian heritage speakers and found that the syntax is basically in place far more than the lexicon.

However, one focus has been word order in subordinate clauses (Taranrød, 2013, Larsson \& Johannessen, 2015a, 2015b), main clauses (Johannessen (2015b), Eide \& Hjelde, 2015), and word order of possessive pronouns (Westergaard \& Anderssen, 2015). ${ }^{4}$ These authors used the American Corpus of American Norwegian, CANS (Johannessen, 2015a), or informants in that corpus, and unpublished, modern heritage Swedish recordings. CANS contains (searchable) transcriptions of recordings from informal interviews and conversations between informants made since 2010, with participants from the core areas of heritage Norwegian in the Upper Midwest (Wisconsin, Minnesota, North Dakota).

If syntactic changes could be explained in terms of transfer, ${ }^{5}$ like the lexicon, we would expect direct influence from English syntax. This does not seem to be the case. Larsson \& Johannessen (2015a, 2015b) illustrate this with embedded clause word order. The baseline (European Scandinavian) relative clause word order Adv-V is illustrated in (1). ${ }^{6}$

a. genseren [som ikke passer]

shirt.DEF.SG that not fits

'the shirt that doesn't fit'

b. * genseren [som passer ikke]

shirt.DEF.SG that fits not

'the shirt that doesn't fit'

\footnotetext{
${ }^{4}$ Norwegian, Swedish and Danish are one language linguistically, mutually intelligible and sharing most vocabulary and much grammar (see Vikør 1995:27-28 or http://www.norden.no/alle-barn-og-unge-skal-laere-om-norden-fordi/.) However, since they are national majority languages in independent countries, they are known as languages, rather than dialects. That they are close enough to be considered one language means that some results can be directly compared. Also, work on one language, for example on acquisition, can be directly used for others.

${ }^{5}$ The term 'transfer' refers to structural patterns of one language applied to another (Selinker 1969).

${ }^{6}$ Larsson \& Johannessen (2015a, b) also discuss that-clause word order, which is different. This will not be discussed here.
} 
In heritage Norwegian, on the other hand, $\mathrm{Adv}-\mathrm{V}$ and $\mathrm{V}-\mathrm{Adv}$ is extremely variable (at a rate of $\sim 50 \%$ ) (see Taranrød (2011). Intra-speaker variation is also evident in the corpus, as in (2).

(2)

a. ... var mye melk der [som ble ikke brukt] was much milk there that was not used

'Was a lot of milk there that wasn't used.'

b. $\quad \ldots[$ som ikke tar mer penger]

who not take more money

'Who don't take out more money.'

(Westby_WI_02gm, from Taranrød, 2011, p. 51)

Johannessen \& Larsson (2015a, 2015b) discuss possible causes: 1) influenced by English ('transfer'), 2) generalised V2 (verb second) from main clauses, 3)

incomplete acquisition, and 4) attrition.

If transfer from English were involved, one would expect similar constructions to English negative clauses, but this was not found. (Only linguistic predictors were explored, not stylistic constraints.) Heritage Scandinavian shows no evidence of constructions like do-support with negation (a man who didn't work there), as in (2) above. There is no syntactic difference between auxiliaries and main verbs (a man who could not work there vs. *a man who worked not there) in heritage Norwegian, as in (2a), containing a negated auxiliary, and (3), with a negated lexical verb.

$\begin{array}{lllllll}\text { Det var mange ord der [som vi } & \text { bruker } & \text { ikke]. } \\ \text { there were many words there that we } & \text { use } & \text { not }\end{array}$

'There were many words there which we use not.'

(Westby_WI_03gk)

A second possibility is that word order variation is caused by overgeneralisation of the Scandinavian V2 pattern. While these languages have V2 main clause word order, English does not, as in the first line and the translation in (4).

(4)

$\begin{array}{llll}\mathrm{Vi} & \text { bruker } & \text { alltid smør på } & \text { potetene } \\ \text { we } & \text { use } & \text { always butter on } & \text { potato.DEF.PL }\end{array}$

'We always use butter on the potatoes.'

If the main clause word order in (4) were generalised to subordinate clauses, the generalisation should have applied across the board. But embedded questions are not generalised to main clause word order. Main clause questions, (5a), have V-Subject order, while heritage (and European) Scandinavian embedded questions have Subject-V order, (5b).

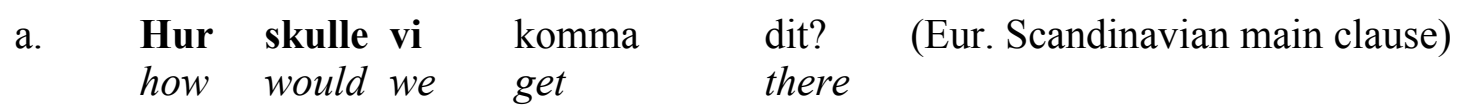


'How would we get there?'

b.
Å vi frågade $[$ hur vi
skulle komma till Björklunds matta]
and we asked how we
would get to Björklund's Rug
'And we asked how we would get to Björklund's rug.'

(Theodor)

Johannessen \& Larsson (2015a, 2015b) conclude that there is no process of generalisation.

They then consider whether incomplete acquisition may be a factor, investigating the clause structure in European Norwegian. Based on evidence from child acquisition, Westergaard \& Bentzen (2007, p. 285) posit several stages of syntactic development, where embedded word order is most difficult, not mastered until school age. They argue that the change must have happened this way: Heritage learners did not fully master the embedded order by the time they went to school. School minimizes exposure to heritage language, and therefore less exposure to constructions like embedded clauses. Relative clauses with adverbs are generally infrequent, meaning that total exposure to relative clauses is low. Heritage children therefore never reached a stable final stage. ${ }^{7}$

Individual attrition seemed not to be a factor, since the many relevant speakers were otherwise fluent and target-like.

Arnbjörnsdóttir, Thráinsson \& Nowenstein (to appear) study main clause word order in North American Icelandic, using grammaticality judgments. While nearly half of the speakers have a clear V2 preference, almost half show variation between $\mathrm{V} 2$ and V3 or preference for V3. They find evidence that the amount and nature of exposure to English during the period of acquisition plays a role in the acquisition of V2, suggesting that a factor for this variation is incomplete acquisition. This is also a feature in heritage Swedish. Hedblom (1978) studies the Hanebo dialect of Sweden spoken by twin sisters, third generation, in Illinois, based on recordings from the 1960s and 1970s. Hedblom gives examples $(6 a, b)$ below, which illustrate English influence (1978, p. 67).

(6)

$\begin{array}{lllllll}\text { a. När } & \text { det } & \text { var } & \text { is } & \text { på vintern han skodde-na } \\ \text { when } & \text { it } & \text { was } & \text { ice } & \text { on } & \text { winter.DEF.SG he shod her }\end{array}$

'When it was ice in winter, he shod her (the mare).' (Target:... skodde han na)

(Hedblom, 1978, pp. 28,66)

$\begin{array}{lll}\text { b. Jag aldrig gör det } & \text { never do it }\end{array}$

'I never do it.' (Target: Jag gör aldrig det)

(Hedblom, 1978, pp. 42,66)

Main clause verb placement is also investigated by Eide \& Hjelde (2015), testing a hypothesis of a positive correlation between V2 and finiteness morphology.

\footnotetext{
7 This explanation is valid for the first generation that changes their grammar this way. The next generation will learn this changed grammar, cf. 1.2.
} 
They find some correlation, i.e. some speakers do not distinguish finiteness, and some do not have V2 consistently (Eide \& Hjelde, 2015, pp. 85, 89), but the categories must be more nuanced to account for systematic variation in different syntactic categories. They focus on one speaker, as does a study by Johannessen (2015b). Word orders diverging from the baseline are very similar across these studies. Both find that V2 is better preserved with short than with long topics. I assume that non-target word order in one informant is attrition due to lack of use over many years (see Stolberg \& Münch, 2009 for a German parallel).

Kühl \& Heegård Petersen (2016, to appear) discuss main clause word order in North American Danish, based on recordings from the 1960s and 1980s of 64 speakers, 49 immigrants from Denmark and 15 born in the US. The general word order for Danish in Denmark, XVS (=V2), is resilient. However, they find XSV (= V3) in $8 \%$ of all main clauses (2016, p. 169). This is surprising compared with results for Norwegian (Eide \& Hjelde, 2015, Johannessen, 2015b), as they find that, at least for adverbial constituents, heavy constituents do not trigger more non-target word order, and that fronted non-subject constituents actually favour the European word order. It is debatable whether the results are comparable, however. ${ }^{8}$ They find no sociolinguistic or demographic correlations with gender or time spent in the US.

If sentences begin with an English lexical item, XSV word order is frequent: Almost $60 \%$ of clauses with an initial element in English have this order, versus only $4 \%$ of others. Further, if the topic is accompanied by an anaphoric particle, the chance of non-target XSV word order is low (only $1.7 \%$ ), as against $6.5 \%$ if the fronted constituent is without the particle, as in (7).

Og efter nogle år så kom de tilbage igjen

and after some years then came they back again

'And after some years they came back again.' (Kühl \& Heegård Petersen, to appear)

In European Norwegian, possessive pronouns can be prenominal or postnominal both used in all dialects, but with dialect and pragmatic differences in distribution. Westergaard \& Anderssen (2015) compare possessives in bilingual children in Norway with heritage Norwegian speakers in the US. A first hypothesis would be that heritage Norwegian speakers use the preposed possessive more frequently, as transfer from English. However, heritage speakers use the postnominal possessive construction more than speakers in Norway. This is unexpected given that it is more syntactically complex than the prenominal possessive, and more different from English. Westergaaard \& Anderssen suggest that the overall token frequency of

\footnotetext{
${ }^{8}$ Kühl \& Heegård Petersen (2016, to appear) exclude one large category (809 sentences) from the count of quantitative heaviness of topics: what they call adverbial connectors: $s a ̊$ 'then, so', $n u$ 'now', $d a$ 'then'. These are quantitatively light, and might have influenced the results.

There may be another reason for why the numbers differ. Kühl \& Heegård (p.c., June15, 2017) counted heavy, left dislocated topics that have been doubled by anaphoric particles as heavy constituents, in contrast with Eide \& Hjelde (2015), p.c., and Johannessen (2015b), who explicitly counts them as light (only the particle is counted). The Danish sentences with a doubled anaphoric particle constitute 287 sentences, see the example in (7), of which 282 $(98.3 \%)$ have the target XVS word order, as against constituents without the particle, which amount to 1329. Most of the anaphor particle sentences are adverbials (274), and adverbials without the particle are almost equal in number (335) (Tables 8 and 9, Kühl \& Heegård Petersen, to appear). Counting them differently might have changed their conclusion.
} 
the postnominal possessive protects it from change. This accords with Van Coetsem (2000, p. 106) and Weinreich (1953, p. 57) who see frequency as promoting stability. Johannessen \& Larsson (2015) discuss gender agreement in Norwegian noun phrases, using CANS. Though many speakers have target-like use of gender, they argue for more non-target agreement the more complex a noun phrase is, concluding that linear complexity (and memory) is a relevant factor in variation and change. Lohndal \& Westergaard (2016) also discuss gender using the same material, looking for a reduction from a three-gender to a two-gender system, which they did not find. However, they did find overgeneralisations of the masculine in some syntactic contexts, which they attribute to attrition. Gender in heritage Norwegian has also been investigated by Rødvand (2017), using two experiments to elicit pronouns showing gender. There was much individual variation and informants had to be grouped into different categories in order to generalise results. Relicts of the original three-gender system existed for virtually all speakers, and the definite suffix was used in a targetlike manner by all (Rødvand 2017, p. 130). Hedblom (1978, p. 60) documents some variation in gender assignment and agreement in the dialect spoken in Illinois, such as ett 'a.N' skåp 'cupboard.N' - den 'the.F/M' skåpø 'cupboard.N.DEF'. Unlike other changes (Section 3.4), this cannot be attributed to influence from Standard Swedish or contact with English.

Hedblom (1978) notes some changes in reflexives in the Swedish Hanebo dialect. It is not systematically investigated, but reflexive possessives seem to have been substituted by pronominal possessives, as in (8):

$\begin{array}{cllll}\text { (8) Han } & \text { tog } & \text { hanses } & \text { gammel } & \text { rullare } \\ \text { he } & \text { took } & \text { his } & \text { old } & \text { roller }\end{array}$

'He took his old roller.'

(Target: 'Han tog sin gamla vält' or even more dialectal: 'Han tog gammelvälten sin'.)

(Hedblom, 1978, p. 62)

Hedblom (1978, p. 63) states explicitly that $\sin$ has, just like in American Swedish generally, been replaced by hans, hennes and deras/deres (also Hasselmo 1974, p. 218).

Putnam \& Arnbjörnsdóttir (2015, pp. 203-223) show that long-distance binding has disappeared in North American Icelandic, but it remains open as to why. They suggest a combination of incomplete acquisition, lack of sustained frequency of input and usage.

Winford (2003, p. 97) claims that syntax very rarely gets borrowed. The data here support this. Changes in heritage Scandinavian syntax are not simply a case of borrowing or transfer. Even when we find patterns that superficially look like English, as in subordinate clauses and main clauses, we would have to explain why only some orders are transferred from English. For example, we would need to show why the English word order in main clauses is only used when the clause-initial topic is long and heavy. Without an account for the lack of English-like word order, transfer (or borrowing) has no explanatory value.

This section has shown that the following factors are relevant for syntax by the cited authors: overgeneralisation (analogy), incomplete acquisition, attrition,

\footnotetext{
${ }^{9}$ Hedblom uses the transcription skåpe. The last character stands for an open ö sound of changing quality, often $e$, $\ddot{a}$, or $a$ coloured ("ett mycket öppet $\ddot{o}$-ljud av skiftande kvalitet,

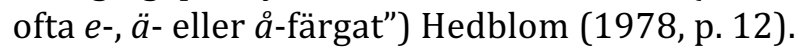


frequency and linear complexity and memory. A factor that has not been argued convincingly to have an effect on syntax is transfer (with the exception of the more lexical substitution of anaphors with pronouns). Other factors that have not been mentioned in the syntactic context by researchers are external ones like the make-up of societal ties, attitudes, prestige and identity.

\subsection{Lexical Changes}

Lexical changes are abundant in any contact setting, cf. Sapir (1949 [1921], p. 193): "The simplest kind of influence that one language may exert on another is the 'borrowing' of words." New words in heritage Scandinavian were noted by Pastor Duus (1855-1858 [1958]) and in letters by laypeople from the 1850s onward (Øverland \& Kjærheim, 1992). Lexical studies of heritage Norwegian started with Flom (1901, 1926), Flaten (1901) and have continued into the 20th century (Haugen, 1953, Hjelde, 1992) and the 21st century (Johannessen \& Laake, 2012, 2017, Grimstad, Lohndal \& Åfarli, 2014, and many others), for Danish since Kjær \& Baumann Larsen $(1972,1987)$, and Swedish since Hedblom (1978). Many of the loanwords mentioned in these and other works have been stable for more than a hundred years.

Johannessen \& Laake $(2012,2017)$ divide loan words into three kinds:

1 ) those referring to things not known in the home country (car, tractor and college), i.e. simple transfer.

2) loan words that replace existing words (ditch for grøft and expect for vente). These could be explained in terms of processing (the words are salient in use in the dominant language), but also by sociolinguistic factors, such as group or network identification and identity construction. Van Coetsem (2000, p. 68), citing Hockett (1958, pp. 404-407), Weinreich (1953, p. 79) and Labov (1972, p. 36ff.), maintains that prestige or a positive orientation towards the community, equated with self-identification, are central motivations for transfer.

3) words that keep the same form, but take new meanings, as in veg 'way' for måte, and gå, changed from 'walk' to 'travel in other ways than by foot', cf. English go. The same words are also found in heritage Swedish and Danish (e.g., Kühl 2015, Larsson et al. 2015.) This type, 'loan-shifting' in the terminology of Clyne (2003), is explained in terms of convergence by Matras (2009), attributed to language processing and cognitive load.

We see that the explanations differ depending on loan type, from transfer due to practical needs (new items) to language processing (lessening the burden of different meanings for the same phonological word), and even to identity (group identification, e.g. using the same words as some important group or network) and attitudes.

\subsection{Phonetic and phonological changes}

Phonological variation and change is well documented in heritage languages. For instance, Benmamoun et al. (2013a, p. 137) report on work on Armenian in the U.S. conducted by Godson (2004) where speakers kept the original Armenian vowel system, but three of the five vowels changed in quality towards English, suggesting transfer. 
Iceland is a country with a strong prescriptive tradition. When in the 1950 s the phonological phenomenon Flámoeli (a derogatory term meaning 'slanted speech', in which two sets of front vowels merged) started and even spread, official efforts and stigmatization soon almost eradicated it. In North American Icelandic, however, it spread without the normative attitudes that existed at home (Arnbjörnsdóttir, 2015, pp. 89-90).

Hjelde (1992) studied the Trøndsk heritage dialect of Norwegian, using material recorded in the Upper Midwest. He found that this heritage dialect has lost the feature [+round] in the realisation of /y/, yielding forms like [br:] for by 'town' and [mI:] for mye 'much'. However, there is still a slight difference between the innovative [I] variant and the old /i/ phoneme, giving minimal pairs like [mI:] mye 'much' and [mi:] $m i$ 'my' (Hjelde, 1992, p. 42).

Hjelde (1992, p. 44) notes that / $\mathrm{r}$ / has also undergone change, from an alveolar to an approximant $/ \mathrm{t} /$, though not necessarily for all words and phonological contexts. He characterises both phenomena as interference from English, while stressing that $/ \mathrm{r} /$ changes for other reasons, too. In European Norwegian this phoneme has gone from alveolar (like in Italian) to uvular (like in French) in many dialects, and this change is still spreading. A main factor is suggested to be group identification, another the articulatory difficulty attached to the alveolar sound, making it vulnerable to interference. The phonological system remains. Hjelde, then, suggests three factors for variation and change: sociolinguistics (group identification), articulation, and interference (transfer).

Heegård Petersen (to appear) has studied 15 phonological phenomena of the Danish Thy dialect in the speakers of a former Danish settlement in South Dakota, recorded 1970-1980. Anticipating dialect convergence, he finds instead two clear groups of speakers: Group 1, born in South Dakota, is more dialectal, while group 2, speakers born in Denmark, is less dialectal (reflecting the regional variant spoken in Denmark at the time of emigration). The speakers have not kept the same features. The amount of inter-individual variation and lack of consistency make it clear that there is no "founder effect", but there is phonological individuation instead. ${ }^{10}$ Heegard Petersen cites Trudgill (2008, p. 253), who argues that prolonged dialect contact always leads to dialect mixture. In South Dakota, it may not have had time to develop. Domain loss started early in North American Danish, to the extent that Norwegian congregations took over Danish ones, because there were so few Danes.

Hedblom (1978) finds that phonology is among the most resistant areas of the dialect in these heritage Swedish third generation speakers (p. 77; see also Benmamoun et al. 2013a). Both quality and quantity of the sounds have been kept, as has the prosody. This section shows that the resistance to change is high for phonology, though phonetic changes can occur and so influence the system.

\subsection{Morphology}

Morphological changes are rarer than lexical ones (Van Coetsem 2000, p. 116). Hjelde (1992) looked for interference or transfer in heritage Norwegian, but found only two certain occurrences of English morphemes, used only once each (a plural $-s$ on and a progressive -ing form). More recently (2015), he examined changes in a Midwestern Norwegian dialect, with data from speakers born as far back as 1849 and

\footnotetext{
10 The "founder effect" is the effect that emigrants are only a subgroup of the original population, and therefore represent less variation, whether genetically or linguistically.
} 
as recently as 1961 . Some morphological levelling in the past tense suffix and dative case suggest incomplete koinéisation. With over 160 years since Norwegians started settling in this area, this is a long time for koinéisation, otherwise often reported to take three generations, ca. 60 years. While one reason for the delay of this process may have been that new immigrants kept coming from Norway over a long period of time, Hjelde suggests that the strong family ties and loyalty towards roots and family were crucial in this slow development (Hjelde 2015, p. 295), cf. "horizontal ties", Section 2.1.

Loanword inflection has been a focus for many researchers (from Haugen 1953 to Riksem, to appear). Riksem (to appear: §6) finds nearly 1,000 English nouns used in heritage Norwegian conversations from CANS. Of these $10 \%$ have plural $-s$. The rest are morphologically integrated into Norwegian. The number of words with $-s$ is so much higher than reported in older literature that it must reflect a change in heritage Norwegian.

For Swedish, Hedblom (1978) notes numerous changes from the original Hanebo dialect in his informants from the three-gender system towards a two-gender system, including changes in pronouns han 'he', hon 'she', den 'it.M/F' and det 'it.N' (p. 77). For some changes it is difficult to determine the cause; Standard Swedish had also influenced dialects in Sweden, so it is possible that the changes were already in flux at the time of immigration by their ancestors. However, Hedblom (p. 60) observes that the original dialect inflections of nouns (the paradigms), adjectives (the inflection of comparison) and verbs ("strong" and "weak") are in place.

\subsection{Semantic changes}

Matras (2009) suggests that lexical items in two languages would converge if they are otherwise similar phonologically. This has clearly happened at the lexical level in North Germanic heritage languages, for example in heritage Icelandic, where vanta 'need' has been relexified to vanta 'want', based on phonological similarity (Arnbjörnsdóttir, 2015, pp. 85-86). Similarly, Johannessen \& Laake (2017) show that a verb like Norwegian $g a ̊$ 'walk' gets a new meaning 'go' in America, and we saw (Section 3.2) that Norwegian veg changed from 'road' to metaphorical 'way' like English.

Arnbjörnsdóttir (2015, p. 87) shows that subjunctive mood in most cases has been replaced by the indicative mood in heritage Icelandic.

\section{Factors influencing variation and change}

As we have seen, heritage language variation and change involves many interacting factors, from linguistic-internal constraints on structure to psycholinguistic factors (including language processing and memory), and sociolinguistic factors (relating to bilingualism, identity construction and group identification). The study of heritage languages can help us understand how language maintenance, change and variation.

\subsection{Observations about variation and change}

Modern contact linguistics traces at least to Haugen (1953) and Weinreich (1953), but heritage language linguistics is fairly new; Benmamoun et al. (2013a) often serves as a reference point. Unanswered questions include: What level of language is affected by what kind of factor? Can attrition happen to any part of language? Does it happen in a certain order? Many factors have been suggested here. 
For lexical changes we have seen explanations in terms of language processing mechanisms, in terms of sociolinguistic factors such as group identification, and of course the need for naming new concepts (Van Coetsem 2000, others). Matras (2007, p. 48) and many others hold that nouns are more borrowable than verbs, perhaps because verbs are more syntactically and morphologically complex. Though quantifying borrowed items is difficult, it is not evident that this constraint holds for heritage Norwegian, as many examples in Section 3.1 are verbs.

Changes in phonetics and phonology have been argued to result from articulatory difficulties, sociolinguistics and interference or transfer. Phonology is most stable, given its inherent, or constitutional (based on structuredness), stability in a recipient language (Van Coetsem 2000, p. 116), and Benmamoun et al. (2013a, p. 153 ) hold that it is the best-preserved area of heritage grammar. Matras (2007, pp. 3637) deals with borrowability, giving three ways in which the phonemic system can change. No phoneme borrowings in Scandinavian languages have been reported, but there have been changes in the realisations of speech sounds. Section 3.3 provides examples of merger, so clearly phonemic change is possible (Arnbjörnsdóttir, 2015, pp. 89-90, Hjelde, 1992, pp. 42, 44).

Few morphological changes are reported, perhaps due to speakers' loyalty to roots and family (Hjelde, 2015), while an official standard may contribute to changes (Hedblom, 1978). In the morphology-syntax interface changes have been attributed to complexity and overgeneralisation (Johannessen \& Larsson, 2015 and Lohndal \& Westergaard, 2016). Van Coetsem (2000, p. 16) sees functors and primary vocabulary that vary along a paradigmatic axis as having maximal stability, meaning that morphological transfer should be rare. Benmamoun et al. (2013a, p. 142) maintain that morphological divergence is more pronounced in the nominal than in the verbal domain. This cannot be properly tested in an interesting way for Scandinavian since there is more nominal morphology, with separate marking for number, gender, definiteness and even case, as against finiteness and tense in the verbal morphology. Nominal morphology is more complex and therefore has more things that can 'go wrong'. Benmamoun et al. (2013a, p. 142) also report that research shows tense morphology to be unaffected. This is not the case for Norwegian finiteness morphology as we saw in 3.4 (Eide \& Hjelde, 2015). Furthermore, they see morphology as the "weakest link" in heritage languages (2013, p. 142), which is not necessarily true with respect to Scandinavian.

For syntactic variation and change, Matras (2007, p. 43) holds two- or threegender systems to be relatively stable. This is also the overall impression from research cited in Section 3.4, despite variation (Johannessen \& Larsson, 2015, Lohndal \& Westergaard, 2016, Rødvand, 2017). He also mentions that the most common change to possessive constructions is word order, often drawing on existing flexibility, exactly what Westergaard \& Anderssen (2015) found. The borrowing of plural markers reported by Riksem (to appear) is supported by Matras (2007, p. 43), who reports them to be easily borrowable, given that they meet the criteria for semantic transparency often noted.

Factors contributing to syntactic change seem to include incomplete acquisition (tied to the age of acquisition and input) (Larsson \& Johannessen, 2015a, 2015b), frequency of a construction (Westergaard \& Anderssen, 2015), loss of finiteness distinctions (Eide \& Hjelde, 2015, p. 85), linear complexity (Johannessen \& Larsson, 2015), and attrition based on lack of usage (Section 3.1). Benmamoun et al. (2013a, p. 148) indicate, however, that syntax is more resilient than the inflectional domain. This is not necessarily true for Scandinavian. The research they report from 
Swedish (Håkansson, 1995) on V2 word order, differs from results reported in 3.1. On the other hand, Håkansson's subjects were all Swedish-born and had lived abroad for some time, thus different from our heritage speakers. Clearly different background and different conditions play a role for the acquisition and attrition of language. Benmamoun et al. (2013a, p. 149) state that heritage speakers have problems with processing syntactic dependencies (binding of anaphors). Not much has been done on this, though Hedblom (1978) and Putnam \& Arnbjörgsdóttir (2015) give examples of anaphoric relations that have been lost. The latter are uncertain about the reasons for this change. One could investigate whether the linear complexity factor mentioned for gender agreement in the noun phrase could have the same kind of explanation as this.

Studies argue (Köpke \& Schmid, 2004, Stolberg \& Münch, 2010) that attrition results from lack of use. Attrition can also be caused by complexity related to cognitive load and memory, which in turn may be related to age or cognitive problems. Although today's heritage speakers are elderly, one assumes that those who serve as language consultants do not have (severe) cognitive decline. However, bringing tests for diagnosing dementia and cognitive impairment into fieldwork with heritage speakers already lacking in confidence would be a delicate matter.

\subsection{The role of attitudes}

Let us consider whether positive attitudes to heritage culture help maintain heritage language against shift. As described in 2.2, all the speakers I have worked with are positive about their heritage. We have, however, also talked to many other nonNorwegian-speaking heritage Norwegians in the same communities, and they are very happy about their Norwegian ancestry, too. Golden \& Lanza (2015) discuss identity construction amongst heritage Norwegians, and find that those whose Norwegian language is faltering place more emphasis on artifacts and cultural traditions. There does not seem to be a correlation between identity and knowledge of the heritage language, as also noted by Litty, Evans \& Salmons (2015, p. 201) for Wisconsin German.

There is much variation in proficiency among speakers. However, they generally have a positive attitude to their heritage language and culture, which indicates that attitudes in the individual are not decisive for fluency of a language, or even keeping a language at all. This is supported by previous studies. Salmons (2005a, 2005b) and Lucht, Frey \& Salmons (2011) show that language shift depends on external factors, especially when strong vertical ties, like a centralised board of education or national religious institutions, displace horizontal ties, among local institutions like schools and churches. The existence of religious communities that have kept their heritage language, such as Pennsylvania Dutch, shows that if the horizontal ties are strong, the general trend of shift can be resisted. In such cases there must be a very strong group attitude towards language preservation.

Still, as researchers we have not met all those people who used to speak Norwegian and do not anymore. According to US census data there were 200,000 Norwegian mother tongue speakers in 1970, while in 2000, 55,000 had Norwegian as a home language (see Fishman, 1991, p. 47, also Johannessen \& Salmons, 2015a, p. 6 ). The declining number indicates that hundreds of thousands, if not millions, over the years have made a conscious or unconscious decision to discontinue the heritage language for themselves and their children. We do not know why, though there was a strong push for 'Americanization' around the Second World War, when many of our 
informants were children, and which meant that being an American and speaking English were important in the US, cf. Section 2.2.

Nagy (this volume) comes to the same conclusion for heritage speakers in Toronto. Other conditions need to be in place for the attitudes to have practical linguistic consequences. Karatsareas (this volume) lays out relevant conditions concerning Cypriot Greeks in London: existing attitudinal systems can be transplanted from old, traditional geographical and social contexts to new ones. Attitudes are preserved in the same social institutions that preserve attitudes in the original geographical and social context. Negative attitudes in transplanted communities target both traditionally stigmatised variants and new variants that develop. While Scandinavian heritage languages belong to the traditional heritage type, the languages described by Nagy and Karatsareas are modern heritage languages. The traditional Scandinavian group have little left by way of inherited attitudes they might have had towards different kinds of their language (Icelandic being a possible exception, see Arnbjörnsdóttir, 2015, p. 76, though Arnbjörnsdóttir, 2015, pp. 89-90 also shows that some norms do not survive in the new world, see Section 3.3). The attitudes they have are towards the language and their heritage culture as such. In this they may differ from modern groups of heritage speakers. But in both cases, attitudes have not proved to be sufficient for change or preservation.

Still, attitudes can play a role in lexical transfer or borrowing (Van Coetsem, 2000, Hockett 1958, and Weinreich 1953). The research reviewed here supports this, and suggests that phonetic changes would be partly linked to attitudes. Figure 1 summarises the factors reviewed. 


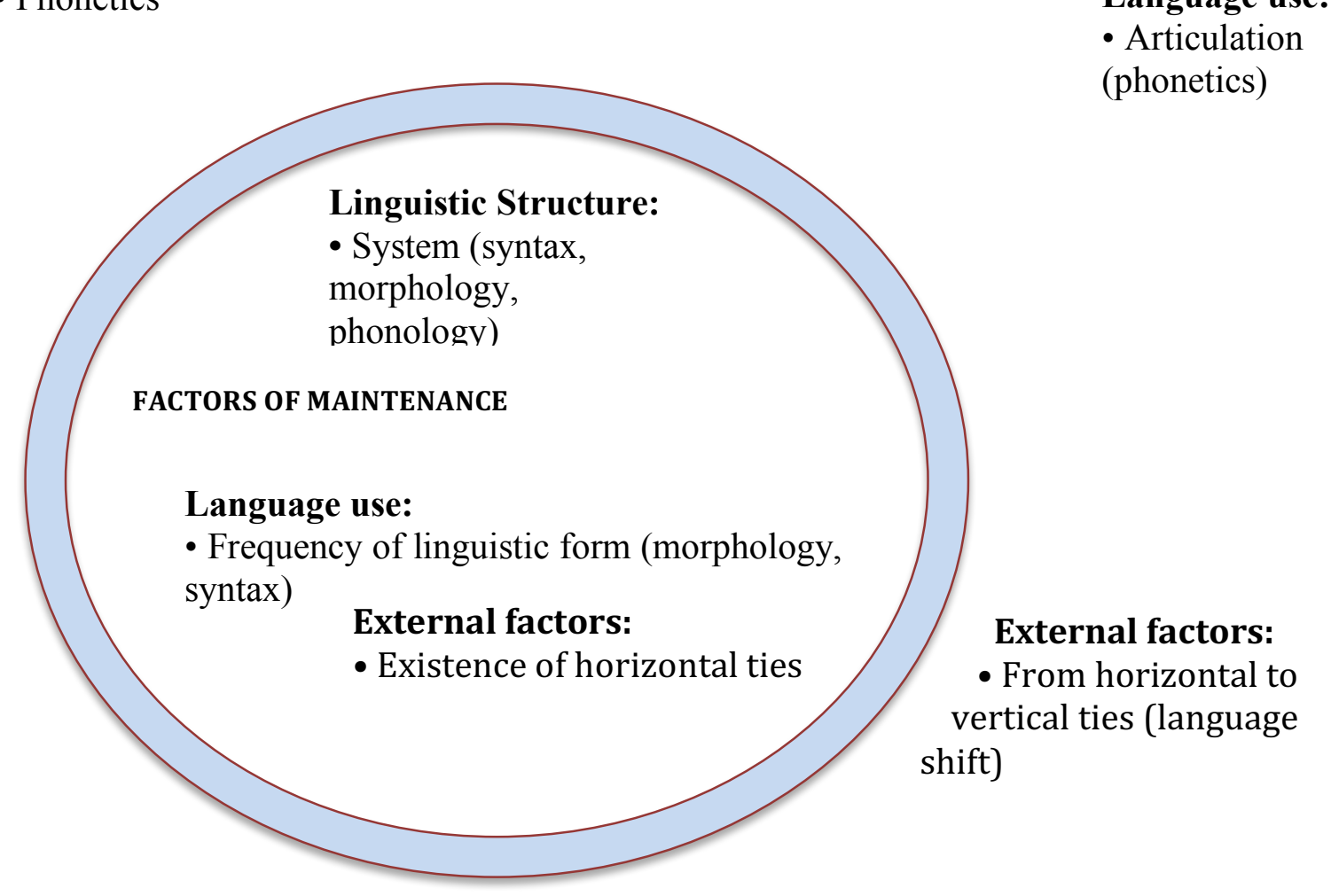

\section{Language cognition:}

- Incomplete acquisition (syntax)

- Transfer and convergence (lexicon, phonetics)

- Attrition (all levels of language)

- Processing, memory and complexity

- Overgeneralisation

Figure 1: Factors for maintenance (inside the circle) and change (outside the circle)

Figure 1 presents a tentative picture of factors relevant for heritage language maintenance and change. Variation is a result of the factors at play and their relative weight will determine whether the result is maintenance, change or ongoing variation.

\section{Conclusion}

I have investigated factors relevant for variation, maintenance and change in heritage languages. My focus on Scandinavian heritage languages in America has the advantage that the languages studied and the social settings are similar (with the exception of Danes, who were less rural than other groups), enabling better comparisons. 
The factors depicted in Figure 1 belong to two main categories: those favouring maintenance (inside the circle) and those that can trigger change (outside). Factors of change are articulation, language attitudes, and a series of cognitive aspects: incomplete acquisition and attrition, transfer and convergence, processing, memory, complexity, and overgeneralisation. Factors of maintenance are linguistic systems (in syntax, morphology and phonology) and token frequency. Attitudes may play a role for both maintenance and change of individual language levels, but do not influence language shift. This latter depends on external factors: horizontal and vertical ties.

Heritage language research combines studies of language structure, language processing and language external conditions, and relates all this to studies of first and second language acquisition. It is therefore ideal for learning more about the relevance of factors that influences linguistic development. There is still very much that is not known about the interplay between the factors and their effect on the different levels of language.

\section{Acknowledgements}

I would like to thank the editors Anita Auer, Jonathan Kasstan and especially Joe Salmons as well as two anonymous reviewers for very valuable comments and insightful suggestions.

\section{Funding}

This research has been partly supported by the Research Council of Norway through its Centre, of Excellence funding scheme, project number 223265.

\section{References}

Arnbjörnsdóttir, B. (2015). Reexamining Icelandic as a heritage language in North America. In J.B. Johannessen \& J. Salmons (Eds.), 72-93.

Arnbjörnsdóttir, B. (2006). North American Icelandic: The Life of a Language. Winnipeg, Canada: University of Manitoba Press

Arnbjörnsdóttir, B, Thráinsson, H. \& Nowenstein, I.E. (To appear). V2 and V3 Orders in North-American Icelandic. Accepted for Journal of Language Contact.

Benmamoun, Montrul, S. \& Polinsky, M. (2013a). Heritage languages and their speakers: Opportunities and challenges for linguistics. Theoretical Linguistics, 39 (3-4): 129-181.

Benmamoun, E., Montrul, S., \& Polinsky, M. (2013b). Defining an "ideal” heritage speaker: Theoretical and methodological challenges. Reply to peer commentaries. Theoretical Linguistics, 39.3-4, 259-294.

Clyne, M. 2003. Dynamics of Language Contact. Cambridge, UK: Cambridge University Press.

Duus, O. F. (1855-1858 [1958]). Frontier Parsonage: The letters of Olaus Fredrik Duus. Norwegian Pastor in Wisconsin, 1855-1858. NAHA, Northfield 1947. In

T. C. Blegen (Ed.), Amerikabrev, H. Oslo, Norway: Aschehoug \& Co.

Godson, L. (2004). Vowel production in the speech of Western Armenian speakers. Heritage Language Journal, 2, 1, 45-70. 
Eide, K. M. \& Hjelde, A. (2015). Verb Second and Finiteness Morphology in Norwegian Heritage Language of the American Midwest. In Page \& Putnam (Eds.), 64-101.

Fishman, J. A. (1991). Reversing Language Shift. Clevedon, UK: Multilingualism Matters.

Flaten, N. (1901). Notes on the American-Norwegian with Vocabulary. Dialect Notes Vol. 2, 115-126.

Flom, G. T. (1901). English Elements in Norse Dialects of Utica, Wisconsin. Dialect Notes, Vol. 2, 1900-1904.

Flom, G. T. (1926). English Loanwords in American Norwegian. As spoken in the Koshkonong settlement, Wisconsin. American Speech, Vol. 1, s.541-558.

Grimstad, M. B., Lohndal, T., \& Åfarli, T. A. (2014). Language mixing and exoskeletal theory: A case study of word-internal mixing in American Norwegian. Nordlyd, 41 (2), 213-237.

Hasselmo, N. (1974). Amerikasvenska: en bok om språkutvecklingen i SvenskAmerika. Stockholm, Sweden: Esselte studium.

Hasselmo, N. (2005). "History of the Scandinavian emigrant languages". In O. Bandle et al. (Eds.), The Nordic languages. An international handbook of the history of the North Germanic languages (pp. 2127-2141). Berlin/New York: de Gruyter.

Haugen, E. (1953). The Norwegian Language in America: A Study in Bilingual Behavior. Philadelphia: University of Pennsylvania Press.

Hedblom, F. (1978). En hälsingedialekt i Amerika. Hanebomål från Bishop Hill, Illinois. Uppsala, AB Lundequistska Bokhandeln, Sweden: Dialekt- och folkminnesarkivet.

Heegård Petersen, J. (To appear). Phonological individuation in a former Danish settlement in South Dakota, USA. Journal of Germanic Linguistics, vol. 30, 2018.

Hjelde, A. (1992). Trøndsk talemål i Amerika. Trondheim, Norway: Tapir.

Hjelde, A. (2015). Changes in a Norwegian dialect in America. In J.B. Johannessen \& J. Salmons (Eds.), 283-298.

Hockett, C. F. (1958). A course in Modern Linguistics. New York: MacMillan.

Håkanson, G. (1995). Syntax and morphology in language attrition. A study of five bilingual expatriate Swedes. International Journal of Applied Linguistics 5 (2), $153-171$.

Johannessen, J. B. (2015a). The Corpus of American Norwegian Speech (CANS). In B. M. (Ed.), Proceedings of the 20th Nordic Conference of Computational Linguistics, NODALIDA 2015, May 11-13, 2015, Vilnius, Lithuania. NEALT Proceedings Series 23, 297-300. Retrieved from http://www.ep.liu.se/ecp/article.asp?issue $=109 \&$ article $=040$.

Johannessen, J. B. (2015b). Attrition in an American Norwegian heritage language speaker. In J. B. Johannessen \& J. Salmons (Eds.), Germanic heritage languages in North America: Acquisition, attrition and change, 46-71. 
Amsterdam: John Benjamins Publishing Company. Retrieved from http://www.jbe-platform.com/content/books/9789027268198

Johannessen, J. B. \& Larsson, I. (2015). Complexity Matters: On Gender Agreement in Heritage Scandinavian. Frontiers in Psychology, Vol 6, Article 1842.

Retreived from

http://journal.frontiersin.org/article/10.3389/fpsyg.2015.01842/full

Johannessen, J. B. \& Laake, S. (2012). Østnorsk som norsk fellesdialekt i Midtvesten. Norsk Lingvistisk Tidsskrift, 30:2, 365-380. Retrieved from https://www.duo.uio.no/handle/10852/41614

Johannessen, J. B. \& Laake, S. (2015). On two myths of the Norwegian language in America: Is it old-fashioned? Is it approaching a written Bokmål standard? In J. B. Johannessen \& J. Salmons (Eds.), 299-322. Retrieved from http://www.jbe-platform.com/content/books/9789027268198

Johannessen, J. B. \& Laake, S. (2017). Lexical evidence for the emergence of an American Norwegian dialect. In Journal of Language Contact 10:1, 5-21. Retrieved from http://booksandjournals.brillonline.com/content/journals/10.1163/1955262901001002

Johannessen, J. B. \& Salmons, J. C. (2012). Innledning. Norsk lingvistisk tidsskrift, Vol 30.(2), 139-148.

Johannessen, J. B. \& Salmons, J. 2015a. The study of Germanic heritage languages in the Americas. In J. B. Johannessen \& J. Salmons (Eds.), 1-18. Retrieved from https://www.duo.uio.no/handle/10852/41613

Kjær, I. \& Larsen, M. B. (1972). Dansk i Amerika: Status og perspektiv. Sprog $i$ Norden, 45-57.

Kjær, I. \& Larsen, M. B. (1987). A study of the vocabulary in an American-Danish community. In S. E. Jørgensen, L. Scheving, \& N. P. Stilling (Eds.), From Scandinavia to America. Proceedings from a conference held at $G l$. Høltegaard (pp. 265-266). Odense, Denmark: Odense University Press.

Kühl, K. \& Heegård Petersen, J. (2016). Ledstillingsvariation i amerikadanske hovedsætninger med topikalisering. Ny forskning i grammatik, Vol. 23, 161176.

Kühl, K. \& Heegård Petersen, J. (To appear). Word Order in American Danish declaratives with a non-subject initial constituent. Journal of Language Contact.

Kühl, K. (2015).'Det er easy at tale engelsk også.' Amerikadansk i 1960'erne og 1970'erne. Nydanske Sprogstudier, 46, 39-64.

Kupisch, T. \& Rothman, J. (2016). Terminology Matters! Why Difference Is Not Incompleteness and How Early Child Bilinguals are Heritage Speakers. International Journal of Bilingualism, 1-19.

Köpke, B. \& M. Schmid. (2004). Language attrition: the next phase. In M. S. Schmid, B. Köpke, M. Keijzer, \& L. Weilemar (Eds.), First Language Attrition: Interdisciplinary perspectives on methodological issues, 1-43. John Benjamins, Studies in Bilingualism.

Labov, W. (1972). Sociolinguistic Patterns. Philadelphia: University of Pennsylvania Press.

Larsson, I. \& Johannessen, J. B. (2015a). Incomplete Acquisition and Verb Placement in Heritage Scandinavian. In R.S Page \& M. T. Putnam (Eds.), Moribund Germanic Heritage Languages in North America: Theoretical Perspectives 
and Empirical Findings, pp. 153-189. Leiden, Netherlands: Brill Academic Publishers.

Larsson, I. \& Johannessen, J.B. (2015b). Embedded word order in Heritage Scandinavian. In M. Hilpert, J.-O. Östman, C. Mertzlufft, \& M. Rießler (Eds.), New Trends in Nordic and General Linguistics, 239-266. Berlin, Germany: Mouton de Gruyter.

Larsson, I., Tingsell, S. \& Andréasson, M. 2015. Variation and Change in American Swedish. In J. B. Johannessen \& J. Salmons (Eds.), 359-388. Retrieved from https://www.duo.uio.no/handle/10852/41613

Litty, S., Evans, C. \& Salmons, J. (2015). Gray zones: The fluidity of Wisconsin German language and identification. (pp. 183-205). In P. Rosenberg (Ed.), Linguistic Construction of ethnic borders. Frankfurt, Germany: Peter Lang.

Lohndal, T. \& Westergaard, M. (2016). Grammatical Gender in American Norwegian Heritage Language: Stability or Attrition? Frontiers in Psycholology, Vol. 7 , Article 344, 1-15. Retrieved from http://journal.frontiersin.org/article/10.3389/fpsyg.2016.00344/full

Lucht, F., Frey, B., \& Salmons, J. (2011). A Tale of Three Cities: Urban and Rural Asymmetries in Language Shift. Journal of Germanic Linguistics 23, 371398.

Matras, Y. (2007). The borrowability of structural categories. In Y. Matras \& J. Sakel (Eds.), Grammatical borrowing in cross-linguistic perspective (pp. 31-73). Berlin, Germany: Mouton de Gruyter.

Matras, Y. (2009). Language contact. Cambridge, UK: Cambridge University Press.

Montrul, S. (2013). How "native" are heritage speakers? Heritage Language Journal 10 (2), 15-39.

Montrul, S. (2010). Dominant language transfer in adult second language learners and heritage speakers. Second Language Research 26 (3), 293-327.

Myhre, J. E.. (2015). Utvandring fra Norge. Norgeshistorie.no Retrieved from: http://www.norgeshistorie.no/industrialisering-og-demokrati/artikler/1537utvandring-fra-norge.html.

Page, B. R. \& M. T. Putnam (Eds.). (2015). Moribund Germanic Heritage Languages in North America - Theoretical Perspectives and Empirical Findings. Leiden: Brill.

Polinsky, M. (2008). Gender under incomplete acquisition: heritage speakers' knowledge of noun categorization. Heritage Language Journal 6 (1), 40-71.

Polinsky, M. (2011). Reanalysis in adult heritage language. New evidence in support of attrition. Studies in Second Language Acquisition 33, 305-328.

Putnam, M. T. \& Arnbjörnsdóttir, B. (2015). Minimizing (interface) domains: The loss of long-distance binding in North American Icelandic. In R. P. \& M. T. Putnam (Eds.), 203-223.

Putnam, M. T. \& Sánchez, L. (2013). What's so incomplete about incomplete acquisition? A prolegomenon to modeling heritage language grammars. Linguistic Approaches to Bilingualism, Vol. 3:4, 478-508.

Riksem, B. R. (To appear). Language mixing in American Norwegian noun phrases. Journal of Language Contact.

Rothman, J. (2009). Understanding the nature and outcomes of early bilingualism: Romance languages as heritage languages. International Journal of Bilingualism, 13, 155-163.

Rødvand, L. I. S. (2017). Empirical investigations of grammatical gender in American Heritage Norwegian. MA thesis in linguistics. University of Oslo, 
Norway: Department of Linguistics and Scandinavian Studies. Retrieved from https://www.duo.uio.no/handle/10852/57359

Salmons, J. (2005a). Community, Region and Language Shift in German-speaking Wisconsin. In L. Hönnighausen, A. Ortlepp, J. Peacock, N. Steiner, \& M. C. Matthews (Eds.), Regionalism in the Age of Globalism: Volume 2: Forms of regionalism, 133-144. Madison: Center for the Study of Upper Midwestern Cultures.

Salmons, J. (2005b). The role of community and regional structure in language shift. In L. Hönnighausen, M. Frey, J. Peacock \& N. Steiner (Eds.), Regionalism in the Age of Globalism: Volume 1: Concepts of regionalism, 129-138. Madison: Center for the Study of Upper Midwestern Cultures.

Sapir, E. (1949 [1921]). Language. An Introduction to the Study of Speech. New York: Harcourt, Brace \& World.

Selinker, L. (1969). Language transfer. General Linguistics, 9.2 : 67.

Stolberg, D. \& Münch, M. (2010). Die Muttersprache vergisst man nicht" - or do you? A case study in L1 attrition and its (partial) reversal. Bilingualism, Language and Cognition, Vol 13:1, 19-31.

Taranrød, B. (2013). Leddstillingen i relativsetninger $i$ amerikansknorsk. MA thesis. University of Oslo, Norway: Department of Linguistics and Scandinavian Studies. Retrieved from https://www.duo.uio.no/handle/10852/26344

Thorsnæs, G. (2014). Norges befolkning. Store Norske Leksikon. Retrieved from https://snl.no/Norges_befolkning

Trudgill, P \& Tzavaras, G. A. (1983). Language contact, language shift and identity. In: P. Trudgill (Ed.), On Dialect: Social and Geographical Perspectices, 12749. Oxford: Blackwell. (Reprint of: Trudgill, P. \& Tzavaras, G. A. (1977): Why Albanian-Greeks are not Albanians: Language shift in Attika and Biotia. In H. Giles (Ed.), Language, ethnicity and intergroup relations. London: Academic Press. 171-184.)

Trudgill, P. (2008). Colonial dialect contact in the history of European languages: On the irrelevance of identity to new-dialect formation. Language in Society $37(2), 241-254$.

Van Coetsem, F. (2000). A general and Unified Theory of the Transmission Process in Language Contact. Heidelberg, Germany: Universitätsverlag C. Winter.

Vikør, L. 1995. The Nordic languages. Oslo, Norway: Novus Press.

Westergaard, M. \& Anderssen, M. (2015). Word Order Variation in Norwegian Possessive Constructions: Bilingual Acquisition and Attrition. In J. B. Johannessen \& J. Salmons (Eds.), 21-45. Retrieved from http://www.jbeplatform.com/content/books/9789027268198

Westergaard, M. \& Bentzen, K. (2007). The (non-) effect of input frequency on the acquisition of word order in Norwegian embedded clauses. In I. Gülzow \& N. Gagarina (Eds.), Frequency Effects in Language Acquisition: Defining the Limits of Frequency as an Explanatory Concept, [Studies on Language Acquisition] (pp. 271-306). Berlin/New York: Mouton de Gruyter.

Weinreich, U. (1953). Languages in Contact. Findings and Problems. The Hague, Netherlands: Mouton.

WILA workshop series (Immigrant Languages in the Americas) http://tekstlab.uio.no/norskiamerika/english/research.html\#Workshop

Winford, D. (2003). An introduction to contact linguistics. Hoboken, NJ: John Wiley $\&$ Sons. 
Østrem, N. O. (2015). Suget frå Amerika. Norgeshistorie.no. Retrieved from http://www.norgeshistorie.no/industrialisering-og-demokrati/artikler/1546suget-fra-amerika.html.

Øverland, O. \& Kjærheim, S. (Eds.). (1992). Fra Amerika til Norge. I norske utvandrerbrev 1838 - 57. Bind 1. Oslo, Norway: Solum. 